\title{
ANALISIS NAMA DIRI ORANG BERBAHASA ARAB DI INDONESIA: KAJIAN MORFO-SEMANTIK
}

\section{ANALYSIS OF ARABIC PERSONAL NAMES IN INDONESIA: A MORPHO-SEMANTIC STUDY}

\author{
Rifa Rafkahanun, Agus Nero Sofyan \\ Universitas Padjadjaran \\ Jalan Raya Bandung Sumedang KM. 21, Hegarmanah, Jatinangor, \\ Kabupaten Sumedang, Provinsi Jawa Barat
}

Ponsel: 082214419260; Pos-el: rifa16003@mail.unpad.ac.id

\begin{abstract}
Abstrak
Bahasa Arab sangat mempengaruhi budaya masyarakat Indonesia, dari mulai banyaknya kosakata bahasa Arab yang diserap ke dalam bahasa Indonesia hingga penggunaan nama diri dari istilah-istilah yang ada dalam bahasa Arab. Penelitian ini membahas mengenai analisis nama diri orang berbahasa Arab di Indonesia berdasarkan kajian morfologi dan semantik dengan tujuan mengklasifikasikan nama diri orang di Indonesia yang diambil dari bahasa Arab berdasarkan kategori kelas kata dan maknanya. Metode yang digunakan untuk menganalisis data dalam penelitian ini adalah padan intralingual translasional dengan teknik pilah unsur penentu yakni nama diri orang Indonesia yang berasal dari bahasa Arab ditransliterasikan ke dalam bahasa Arab lalu dianalisis kategori kelas katanya berdasarkan teori morfologi bahasa Arab. Adapun penyajian hasil analisis data digunakan metode deskriptif kualitatif. Berdasarkan hasil penelitian, secara morfologis disimpulkan bahwa nama diri berbahasa Arab di Indonesia berasal dari empat kategori kelas kata yaitu (1) nomina, yang terdiri dari nomina nama diri seperti Ahmad dan Ramadhan, nomina jenis seperti Zahra dan Ma'arif, nomina subjektif seperti Arif dan Faizah, nomina objektif seperti Muntazhar dan Mubarak, serta nomina deverba seperti Rahmat dan Ridwan; (2) verba seperti Tsabita dan Faza, (3) adjektiva seperti Akbar dan Jamilah, dan (4) numeralia seperti Alfa dan Tsany.
\end{abstract}

Kata-kata kunci: nama diri orang Indonesia; serapan bahasa Arab; morfo-semantik 


\begin{abstract}
Arabic greatly influences the culture of Indonesian society, from the abundance of Arabic vocabulary absorbed into Indonesian to the use of personal names in Arabic. This study discusses the analysis of Arabic personal names in Indonesia based on morphological and semantic studies aimed at classifying the personal names of Indonesian Arabic Names based on their categories and meanings. The method used to analyze the data is a translational identity method with dividing key factors technique. Practically, Arabic Indonesian name is transliterated into Arabic, then categorised morphologically, and finally translated to see the equivalent meaning. Descriptive method is used in presenting the result. Based on the results of the study, it is morphologically concluded that Arabic personal names in Indonesia formed from four categories of word classes: (1) nouns, which consist of proper name such as Ahmad and Ramadhan, type nouns such as Zahra and Ma'arif, subjective nouns such as Arif and Faizah, objective nouns such as Muntazhar and Mubarak, deverbal nouns such as Rahmat and Ridwan; (2) verbs such as Tsabita and Faza, (3) adjectives such as Akbar and Jamilah, (4) numerals such as Alfa and Tsany.
\end{abstract}

Keywords: Indonesian personal name; Arabic loan; morphosemantic

\section{Pendahuluan}

Menurut Kamus Besar Bahasa Indonesia (KBBI) daring, 'nama' adalah kata untuk menyebutkan atau memanggil seseorang, pun juga tempat, barang, binatang dan sebagainya. Apabila dihubungkan dengan bidang linguistik atau kebahasaan, istilah yang lebih dikenal adalah 'nama diri' atau proper name yang berarti 'nama orang, tempat atau benda' (Kridalaksana, 2008: 161 dalam Khotimah dan Febriani, 2019: 52). Sibarani (2004) dalam Hakim (2017: 20) mengemukakan bahwa nama adalah harapan dan doa. Dengan sebuah nama, seseorang akan berikhtiar untuk menjadi diri sendiri dan juga mewujudkan harapan yang terkandung dalam namanya itu.
Ascalonicawati (2019) dalam Achsani (2020: 90) menyebutkan bahwa nama bukan sekadar sapaan, namun juga merupakan harapan dari orang tua yang memberikan nama. Oleh karena itu orang tua lazimnya akan memberikan anaknya nama yang indah baik bentuk luarnya maupun makna yang terkandung di dalamnya. Penamaan seseorang biasanya didasarkan pada latar belakang tertentu, di antaranya adalah faktor budaya seperti waktu ataupun urutan kelahiran (Dewi dkk., 2012 dalam Achsani, 2020: 90).

Bahasa Indonesia adalah bahasa nasional Negara Kesatuan Republik Indonesia yang salah satu fungsinya adalah bahasa negara termasuk dalam hal penamaan (Akmaluddin, 2018: 2). Namun penamaan yang diwajibkan menggunakan bahasa Indonesia hanyalah penamaan di 
ruang publik. Adapun nama diri, setiap warga memiliki kebebasan untuk pemberian nama kepada anaknya. Apabila diselisik lebih jauh, nama yang berasal dari bahasa Arab sangat populer di kalangan masyarakat Indonesia yang mayoritas beragama Islam, seperti nama Muhammad dan Annisa yang sering ditemukan pada nama-nama orang Indonesia. Hal tersebut menyebabkan masyarakat Indonesia begitu dekat dengan bahasa Arab yang merupakan bahasa agama Islam.

Bahasa Arab sangat mempengaruhi budaya masyarakat Indonesia, dari mulai banyaknya kosakata yang diserap ke dalam bahasa Indonesia seperti nama hari senin yang diambil dari kata إنْنَيْن /itsnain/ yang berarti '(hari) kedua', hari selasa yang diambil dari kata ثُلَّنَاء /tsulatsa/ yang berarti '(hari) ketiga' dan seterusnya hingga penggunaan nama diri dari istilahistilah yang ada dalam bahasa Arab seperti Nur yang diambil dari kata نُو /nuur/ yang berarti 'cahaya' dan Zahra yang diambil dari kata زَهَرَ/zahrah/ yang berarti 'bunga'.

Salah satu faktor yang melatarbelakangi hal tersebut adalah kedatangan bangsa Arab ke Indonesia untuk berdagang dan menyebarkan agama Islam. Hal tersebut menimbulkan adanya interaksi sosial antara pendatang dari bangsa Arab dan pribumi (Hidayah, 2018: 102). Adanya kontak berkelanjutan dalam jangka waktu yang lama antar penutur berbeda mengakibatkan terjadinya penyerapan bahasa (Rohbiah dkk., 2019: 320). Bahasa Arab memiliki peranan penting dalam perbendaharaan kosakata bahasa Indonesia daripada bahasa lain (Dopi, 2019: 3). Penyerapan kosakata yang berasal dari bahasa Arab cenderung bertujuan untuk melengkapi kosakata dalam kehidupan sehari-hari yang dibutuhkan pada kehidupan masyarakat (Pulungan dkk., 2019: 34).

Kajian mengenai nama diri dalam linguistik disebut dengan antroponimi (Aprilina, 2016: 71). Penelitian mengenai nama diri di Indonesia sebelumnya telah dilakukan oleh Hakim (2017) yang menganalisis reperesentasi nama diri dalam pemilihan rektor di Universitas Gadjah Mada 2012. Penelitian tersebut membahas makna dan pengaruh nama diri terhadap citra seorang rektor berdasarkan kajian semiotik. Selanjutnya penelitian Khotimah dan Ferdiani (2019) yang membahas nama diri mahasiswa Madura di Prodi Pendidikan Bahasa dan Sastra Indonesia Universitas Turnojoyo Madura yang mengkaji nama diri berdasarkan maknanya untuk mengetahui akulturasi 
antara kebudayaan Jawa dan Madura melalui nama diri tersebut. Achsani (2020) menganalisis nama diri masyarakat Banaran-Bugel secara diakronis dari generasi milenial hingga generasi alfa untuk dilihat perubahannya dan faktor budaya yang mempengaruhinya. Adapun penelitian mengenai nama diri berbahasa Arab telah dilakukan oleh Ubaidillah (2011) namun hanya terfokus pada interferensi penggunaan nama diri berbahasa Arab di Indonesia dengan menggunakan kajian sosiolinguistik.

Pada penelitian ini, analisis nama diri berbahasa Arab di Indonesia bertujuan untuk mengetahui bagaimana bentuk kategori kelas kata dan maknanya dalam bahasa Arab berdasarkan kajian morfologi dan semantik. Khotimah dan Febriani (2019: 52) menyebutkan bahwa semantik menjadi salah satu teori dalam mengkaji nama diri terutama pada penamaan orang.

\section{Landasan Teori}

Untuk menganalisis nama diri orang di Indonesia yang diambil dari bahasa Arab berdasarkan kelas katanya, penelitian ini menggunakan teori utama Nur (2018: 27) yang mengemukakan bahwa kelas kata atau jenis kata dalam gramatika bahasa Arab terbagi menjadi tiga kelompok, yaitu (1) nomina atau isim, (2) verba atau fi'il dan (3) partikel atau harf. Untuk menunjang penelitian ini, penulis mengombinasikan pendapat Moeliono (2017: 193 dan 357) yang menyebutkan (4) adjektiva dan (5) numeralia sebagai kelas kata.

\subsection{Nomina}

Ghulayaini (2017: 85) menyebutkan mengenai nomina dasar yang terdiri dari nomina jenis (ismul jinsi) dan nomina nama diri (ismul 'alam). Nomina jenis atau ismul jinsi adalah nomina yang tidak dikhususkan kepada satu pun dari salah satu jenisnya, seperti kata perempuan, rumah dan kuda. Sedangkan nomina nama diri atau ismul 'alam adalah nomina yang menunjukkan kepada sesuatu yang tentu tanpa terikat kondisi apa pun, seperti nama-nama negara, orang, suku, sungai, laut dan gunung. Adapun dalam tata bahasa Indonesia, menurut Moeliono dkk. (2017: 264) nomina berdasarkan jenis acuannya dapat dikelompokkan atas (1) nomina umum dan (2) nama diri.

Selanjutnya dalam menganalisis kelas kata pada nama diri orang berbahasa Arab digunakan teori mengenai pembentukan nomina turunan yang mengacu pada pendapat Nur (2018: 146). Nomina subjektif atau yang disebut dengan isim fa'il dalam bahasa Arab termasuk kepada nomina turunan atau isim 
musytaq yang diturunkan dari verba melalui proses yang dinamakan tashrif istilahi. Pembentukan nomina-nomina turunan dalam bahasa Arab sudah memiliki pola-pola atau wazan-wazan tertentu.

Nomina subjektif dalam bahasa Arab mengikuti pola فَاعِلِ /faa'ilun/ apabila berasal dari verba dasar triliteral (tsulatsi mujarrad). Sebagai contoh adalah kata كَاتثبِ /kaatibun/ 'penulis' yang diturunkan dari verba كَتبَ /kataba/ 'menulis'. Namun jika diturunkan dari verba triliteral yang berafiks (tsulatsi mazid), maka pola pembentukannya dengan cara memberi prefiks mim yang berharakat dhammah di awal verba tsulatsi mazid sebagai ganti dari fonem pertama pada verba tersebut, lalu fonem sebelum akhir diberi harakat kasrah. Sebagai contoh yaitu kata مُسَافِرِ /musaafir/ 'pelancong' yang diturunkan dari verba سَافَرَ /saafaral 'bepergian'. Wazan-wazan atau pola-pola tersebut menjadi pemarkah bagi pelaku atau nomina subjektif dalam bahasa Arab.

Pembentukan nomina objektif atau isim maf'ul dalam bahasa Arab mengikuti pola حَفْعُوْلِ /maf'uulun/ apabila berasal dari verba triliteral yang tidak berafiks (tsulatzi mujarrod), seperti kata sَعْلُوْمُ /ma'luumum/ 'yang diketahui' yang merupakan turunan dari verba عَلَْ /'alimal 'mengetahui'.
Adapun jika berasal dari verba triliteral yang berafiks (tsulatsi mazid), maka diberi prefiks mim yang berharakat dhammah di awal verba tsulatsi mazid sebagai ganti dari fonem pertama pada verba tersebut, lalu fonem sebelum akhir diharakatkan fathah. Sebagai contoh yaitu kata مُكَرَّمُ /mukarramun/ 'yang dimuliakan' adalah turunan dari verba triliteral berinfiks senggandaan konsonan kedua |karrama/ 'memuliakan'.

Nomina deverba atau yang dikenal dengan isim mashdar dalam bahasa Arab merupakan nomina turunan dari verba yang menunjukkan pada keadaan atau peristiwa yang tidak terikat oleh kala atau tenses. Nomina deverba yang berasal dari verba triliteral tak berafiks (fi'il tsulatsi mujarrad) adalah qiyasi yakni memiliki pola tertentu yang dapat dijadikan ukuran, misalnya pola فَ فَّمْ /fu'lun/ yang menjadi شُرْبْ شَرِبَ 'syurbun/ 'minuman' dari verba /syaribal 'minum'. Namun ada juga mashdar yang bersifat sima'i yakni didasarkan pada pendengaran bagaimana penggunaannya oleh penutur Arab, seperti verba زَرَعَ /zara'al 'bertani' yang زِرَاعَة /ziraa'ah/ 'pertanian'.

\subsection{Verba}

(C)2021, Mabasan 15 (1), 79--94 
Verba bahasa Arab biasanya atau hurufun nidaa, seperti /yaal 'hai' terbentuk dari tiga akar konsonan dan /hayyaal 'mari'; partikel lokatif (Qahtani, 2003: 11 dalam Nur, 2018: 121). atau zharful makan seperti فَوْْقَ /fauqal 'di Ketiga akar konsonan tersebut mendapat atas' dan itahtal 'di bawah'; serta vokalisasi agar dapat diujarkan sebagai kata yang bermakna dalam bentuk polapola verba. Terdapat tiga fonem semivokal dalam bahasa Arab yang menjadi masalah untuk pembentukan verba, yaitu I/alif/, g /waul dan ي ا Fal. Fonem-fonem tersebut dianggap lemah, sehingga dalam proses konjugasi verba banyak mengakibatkan proses morfofonemis.

Berdasarkan komposisi akarnya, dengan melihat ada tidaknya akar-akar lemah dari ketiga fonem semivokal tersebut, verba dalam bahasa Arab terbagi menjadi dua: (1) verba shahih atau strong verbs, yaitu verba yang pada akar-akarnya tidak terdapat fonem lemah, (2) verba mu'tal atau weak verbs, yaitu verba yang sebagian akarnya berupa fonem-fonem lemah (Haywood dan Nahmad, 1962: 191 dalam Nur, 2018: 122).

\subsection{Partikel}

Partikel atau yang dalam bahasa Arab disebut dengan harf meliputi preposisi atau huruful jarr, seperti إلَّى lilaal 'ke', مِ /min/ 'dari', dan لِ /li/ 'untuk'; konjungsi atau huruful 'athfi, seperti و /wal 'dan', مَ 'kemudian', dan أَ و أْ /au/ 'atau'; interjeksi partikel temporal atau zharfuz zaman,

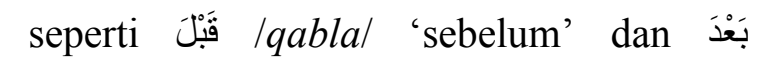
|ba'dal 'sesudah'.

\subsection{Adjektiva}

Adjektiva merupakan kata yang memberikan keterangan mengenai sesuatu yang dinyatakan oleh nomina. Keterangan tersebut dapat berupa pengungkapan kualitas tertentu dari nomina yang diterangkan (Moeliono, 2017: 193). Dalam bahasa Arab, adjektiva disebut dengan shifat namun biasanya dikaitkan dengan pembahasan fungsi sintaksis kata. Secara morfologis, adjektiva dalam bahasa Arab tidak memiliki perbedaan dengan nomina. Oleh karena itu, adjektiva dan nomina dalam bahasa Arab dibedakan melalui maknanya. Di antara yang termasuk adjektiva adalah kata كَبيْر /kabiirun/ 'besar', وَاسِعْ /waasi'un/ 'luas' dan نَظِيْنْ /nazhiifun/ 'bersih'.

\subsection{Numeralia}

Moeliono, dkk. (2017: 357) menjelaskan, kata bilangan atau numeralia merupakan kata yang digunakan untuk menghitung banyaknya entitas (misalnya: orang, binatang, atau barang) dan konsep. Pada dasarnya terdapat dua macam 
numeralia, yaitu (1) numeralia pokok yang disebut juga numeralia kardinal dan (2) numeralia tingkat yang disebut juga numeralia ordinal.

Dalam bahasa Arab, numeralia pokok disebut dengan 'adad dan numeralia tingkat disebut dengan murattab. Di antara contoh 'adad adalah

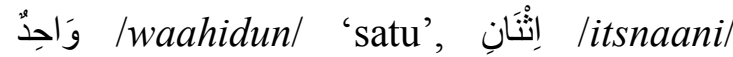
'dua', أَرْبَعَةُ 'tsalaatsatun/ 'tiga', larba'atun/ 'empat' dan seterusnya. Sedangkan murattab dibentuk dari 'adad فَاعِلْ dimasukkan kepada pola /faa'ilun/, seperti kata ثَالِّف /tsaalitsun/ 'ketiga' dan رَابِع /raabi'un/ 'keempat'.

\section{Metode Penelitian}

Penelitian ini merupakan penelitian deskriptif kualitatif yang menyajikan hasil penelitian dengan mendeskripsikan fakta ataupun fenomena yang ditemukan dalam bentuk deskripsi kualitatif, bukan dengan data yang bersifat kuantitatif atau statistik. Menurut Sugiyono (2013: 13) penelitian kualitatif lebih menekankan pada informasi serta data yang terkumpul dalam bentuk kata-kata atau gambar dan tidak menekankan pada angka.

Adapun metode yang digunakan untuk menganalisis data dalam penelitian ini adalah padan intralingual dengan teknik pilah unsur penentu. Metode padan merupakan metode analisis data dengan alat penentu yang berada di luar, terlepas dan bukan bagian dari bahasa yang sedang diteliti (Sudaryanto, 2015: 13). Penelitian ini menggunakan alat penentu di luar bahasa Indonesia, yaitu teori bahasa Arab yang dijadikan alat untuk mengidentifikasi satuan nama diri orang di Indonesia. Metode padan yang digunakan adalah padan translasional karena menjadikan bahasa lain sebagai alat penentu (Subroto, 1992: 59 dalam Ubaidillah, 2011: 4).

Adapun objek pada penelitian ini yaitu nama diri orang berbahasa Arab yang diambil dari nama-nama masyarakat RW 07 Kelurahan Cipadung, Kecamatan Cibiru, Kota Bandung, Provinsi Jawa Barat. Pemilihan nama diri orang di kalangan masyarakat RW 07 Kelurahan Cipadung ini didasarkan pada banyaknya data nama diri masyarakat yang menggunakan bahasa Arab. Selain itu penduduk di daerah tersebut banyak yang merupakan perantau sehingga dapat menjadi sampel atau merepresentasikan nama-nama masyarakat di Indonesia. Penelitian ini dilakukan pada bulan Desember 2020 dengan mengumpulkan data nama diri orang berbahasa Arab menggunakan metode simak yang dilanjutkan dengan teknik catat, yakni mengumpulkan daftar nama diri 
masyarakat dari pengurus Pemberdayaan Kesejahteraan Keluarga (PKK) lalu dicatat nama-nama yang berasal dari bahasa Arab dengan mengecek Kamus Bahasa Arab. Dari pengumpulan data tersebut, terkumpul 81 nama diri orang yang berasal dari kata berbahasa Arab. Data tersebut kemudian diklasifikasikan berdasarkan jenis atau kategori kelas kata yang sesuai dengan landasan teori dan dianalisis berdasarkan bentuk morfologis dan maknanya.

\section{Pembahasan}

Berdasarkan hasil penelitian, secara morfologis nama diri berbahasa Arab di Indonesia terbentuk dari empat jenis kategori kelas kata, yaitu 1) nomina, yang terdiri dari: nomina jenis, nomina diri, nomina subjektif, nomina objektif dan nomina deverba; 2) verba; 3) adjektiva; dan 4) numeralia. Pada penelitian ini tidak ditemukan jenis kategori kelas kata harf atau partikel pada nama diri orang berbahasa Arab di Indonesia.

\subsection{Nama Diri Kategori Nomina}

Pada nama diri orang berbahasa Arab di Indonesia yang termasuk kategori nomina, ditemukan beberapa jenis sebagaimana pada Tabel 1, yaitu nomina nama diri, nomina jenis, nomina subjektif, nomina objektif dan nomina deverba.
Tabel 1

Nama Diri Kategori Nomina

\begin{tabular}{ll}
\hline \multicolumn{1}{c}{ Nama Diri } & \multicolumn{1}{c}{ Jenis Nomina } \\
\hline Ahmad & Nomina Nama Diri \\
\hline Ramadhan & Nomina Nama Diri \\
\hline Zahra & Nomina Jenis \\
\hline Ma'arif & Nomina Jenis \\
\hline Arif & Nomina Subjektif \\
\hline Faizah & Nomina Subjektif \\
\hline Muntazhar & Nomina Objektif \\
\hline Mubarak & Nomina Objektif \\
\hline Rahmat & Nomina Deverba \\
\hline Ridwan & Nomina Deverba \\
\hline
\end{tabular}

\subsubsection{Nomina Nama Diri}

Di antara nama yang termasuk kepada nomina nama diri adalah 'Ahmad' dan 'Ramadhan'. Kedua nama tersebut adalah kata yang biasa digunakan untuk nama seseorang dalam bahasa Arab. أَحْمَد Berdasarkan kamus Al-Ma'any, kata lahmad/ berarti nama bahasa Arab bergender maskulin yang berpola tafdhil atau superlatif (mengikuti pola أَفْعَنُ /af'alu/). Disebutkan bahwa maknanya adalah orang yang dihiasi dengan sifatsifat paling mulia, oleh karena itu maka orang-orang memujinya. Secara literal, nمَدِ 'Ahmad' berasal dari verba /hamidal 'memuji'. Nama ini pun merupakan salah satu nama dari Rasulullah saw.

Adapun nama 'Ramadhan' adalah nama bulan kesembilan pada kalender hijriah. Pada kamus Al-Ma'any, kata رَمَضَان /ramadhan/ dijelaskan sebagai 
nama bahasa Arab yang bergender maskulin dan merupakan nama bulan di mana umat muslim berpuasa. Dalam bahasa Arab, kata tersebut termasuk kepada isim ghair munsharif atau nomina yang tidak bisa menerima tanwin.

\subsubsection{Nomina Jenis}

Nama diri orang yang termasuk kepada nomina jenis dalam bahasa Arab adalah nama 'Zahra' dan 'Ma'aarif'. Kedua kata tersebut memang berasal dari bahasa Arab, namun bukan merupakan nama diri atau isim 'alam. Nama 'Zahra' sendiri berasal dari kata bahasa Arab زَهْرَةْ /zahratun/ yang memiliki arti 'bunga'. Diperjelas dalam kamus Al-Ma'any, bahwa itu merupakan bagian tanaman atau pohon yang muncul dari kuncup dan mengandung alat reproduksi. Namun kata زَهَهْرَة /zahratun/ juga bisa berarti nama orang feminin bagi orang Arab yang memiliki makna ringan tapi dapat membangkitkan kebahagiaan. Kata tersebut dalam bahasa Arab termasuk kepada isim jamid atau nomina dasar yang tidak diturunkan dari verba (Ghulayaini, 2017 :181).

Adapun nama 'Ma'arif' adalah kata bahasa Arab yang berarti 'pengetahuanpengetahuan'. Kata مَعَارِف /ma'aarifl adalah bentuk jamak dari مَعْرِفَ /ma'rifah/

C2021, Mabasan 15 (1), 79--94 'pengetahuan' yang diturunkan dari verba /'arafa/ 'mengetahui'.

\subsubsection{Nomina Subjektif}

Nomina subjektif atau isim fa'il dalam bahasa Arab berarti pelaku atas suatu perbuatan. Isim fa'il termasuk kepada kategori isim musytaq atau nomina turunan. Al-Ghulayaini (2017: 181) menjelaskan bahwa isim musytaq adalah nomina yang diambil atau diturunkan dari suatu fi'il atau verba. Berdasarkan pola pembentukan isim fa'il, ditemukan beberapa nomina subjektif yang dijadikan nama diri oleh masyarakat Indonesia. Di antaranya yaitu 'Arif' dan 'Faizah'

Nama 'Arif' berasal dari kata bahasa Arab عَارِفْ /'aarifl 'yang mengetahui', mengikuti pola فَاعِلْ /faa'ilun/ karena diturunkan dari verba triliteral tak berafiks (tsulatsi mujarrad) عَرَفَ /'arafal 'mengetahui'. Dalam kamus Al-Muhith disebutkan bahwa عَارفت /'aarifl berarti yang megetahui atau mendapatkan suatu informasi. Sedangkan dalam kamus $\mathrm{Al}$ Ma'any dijelaskan bahwa kata tersebut juga merupakan nama maskulin dalam bahasa Arab yang memiliki arti salah satu keluarga Allah yang berilmu, mengetahui kebesaran Allah dan penyabar. Kata 'arif' sendiri sudah diserap ke dalam bahasa Indonesia. Menurut KBBI daring, 'arif' termasuk kepada kategori adjektiva yang 
berarti bijaksana; cerdik dan pandai; berharakat dhammah, lalu fonem sebelum berilmu; paham; dan mengerti.

Adapun nama 'Faizah' berasal dari kata bahasa Arab dengan pola isim fa'il yang sama yaitu فَائزْ "yaaizun/ 'yang berhasil' atau 'pemenang' ditambah sufiks :/ta marbuthah/ sebagai penanda gender feminin. Kata tersebut merupakan turunan dari verba triliteral فَاز /faaza/ yang berarti 'berhasil' atau 'sukses'.

\subsubsection{Nomina Objektif}

Nomina objektif atau yang disebut dengan isim maf'ul dalam bahasa Arab, termasuk pula kepada isim musytaq atau nomina turunan yang bermakna sesuatu yang dikenakan oleh pekerjaan atau verba. Adapun nama diri orang di Indonesia yang mengikuti pola pembentukan isim maf'ul di antaranya adalah 'Muntazhar' dan ' Mubarak'. Kedua nama tersebut berasal dari verba triliteral berafiks yang diturunkan kepada bentuk isim maf'ul. Nama 'Muntazhar' berasal dari bahasa Arab مُنْنَظَر /muntazharun/ 'yang ditunggu', diturunkan dari verba إنْنْظَرَ /intazharal 'menunggu' yang memiliki akar /nazhara/ lalu diberi prefiks ! / i/ dan infiks $َ$ /ta/. Sesuai kaidahnya, pola pembentukan isim maf'ul dari verba triliteral berafiks (tsulatsi mazid) yaitu dengan mengganti huruf awal verba nonlampaunya يَنَظِرِ lyantazhiru/ dengan prefiks /a/ mim atau nomina turunan. Sebagai bentuk

Al-Ma'any, nama مُنْنَظَرْ /muntazharl memiliki makna yang diharapkan kedatangannya.

Sedangkan nama 'Mubarak' berasal dari kata bahasa Arab مُبَارَكَ yang merupakan bentuk turunan isim maf'ul dari verba triliteral berafiks (tsulatsi mazid) بَارَكَََ lbaarakal 'memberkahi' yang berasal dari akar بَرَكَ بَ بَ /barakal ditambah infiks berupa I /alifl atau pemanjangan vokal akar pertama. Pola pembentukannya sama dengan nama 'Muntazhar', yaitu mengganti huruf pertama dari verba nonlampaunya يُبَارِكُ /yubaariku/ dengan prefiks /a/ mim yang berharakat dhammah, lalu fonem sebelum akhirnya diharakatkan fathah. Dalam kamus Al-Mu'ashirah disebutkan bahwa مُبَارَكَك /mubaarak/ adalah kata yang sering diucapkan ketika memberikan ucapan selamat atas kebahagiaan seseorang, seperti pernikahan atau kesuksesan. Kata ini juga sudah diserap ke dalam bahasa Indonesia, yang menurut KBBI bermakna mendapat berkat.

\subsubsection{Nomina Deverba}

Sama seperti isim fa'il dan isim maf'ul, nomina deverba atau isim mashdar ini termasuk kepada kategori isim musytaq 
pekerjaan yang tidak terikat kala, isim mashdar tidak memiliki pola khusus seperti isim musytaq lainnya, melainkan qiyasi atau sima'i sebagaimana telah dijelaskan pada landasan teori.

Adapun nama diri di Indonesia yang termasuk kepada isim mashdar dalam bahasa Arab, yaitu 'Rahmat' dan 'Ridwan'. Nama 'Rahmat' berasal dari kata bahasa Arab رَحْمَةُ /rahmatun/ 'kasih sayang' yang diturunkan dari verba triliteral tak berafiks (tsulatsi mujarrad) /rahima/ yang berarti 'mengasihi' atau 'menyayangi'. Bentuk nomina deverba ini mengikuti pola atau wazan qiyasi /fa'latun/ sebagaimana disebutkan dalam Nur (2018: 160). Dalam kamus Al-Ma'any disebutkan bahwa رَحْمَةُ /rahmatun/ adalah salah satu sifat Rasulullah saw. yang disebutkan dalam Al-Qur'an. Kata ini pun telah diserap oleh bahasa Indonesia dan bermakna belas kasih; karunia (Allah Swt.); dan berkah (Allah Swt.) sebagaimana disebutkan dalam KBBI daring.

Sedangkan nama 'Ridwan' berasal dari kata bahasa Arab رِضْوَانُ /ridhwaanu/ 'keridaan' yang merupakan isim mashdar turunan dari verba triliteral tak berafiks (tsulasti mujarrad) رَضِيَ /radhiyal 'rida'. Pola pembentukan nomina ini adalah فِعَلَنُ /fi'laanu/ namun bersifat sima'i. Dalam kamus Al-Ma'aany disebutkan bahwa رِضْوَانُ /ridhwaanu/ bermakna rida dan menerima, juga merupakan nama malaikat penjaga surga.

\subsection{Nama Diri Kategori Verba}

Selain kategori kelas kata nomina, nama diri orang berbahasa Arab di Indonesia juga ditemukan dalam bentuk kategori verba. Beberapa nama diri yang berkategori atau berada pada kelas kata verba ini terbagi kepada strong verbs ( $f i$ 'il shahih) dan weak verbs (fi'il mu'tal) sebagaimana dalam Tabel 2.

\section{Tabel 2} Nama Diri Kategori Verba

\begin{tabular}{ll}
\hline \multicolumn{1}{c}{ Nama Diri } & \multicolumn{1}{c}{ Jenis Verba } \\
\hline Tsabita & Strong Verbs \\
\hline Faza & Weak Verbs \\
\hline
\end{tabular}

Di antara nama yang berasal dari kata bahasa Arab berkategori verba adalah 'Tsabita' dan 'Faza'. Kedua nama tersebut sama-sama berasal dari verba triliteral tak berafiks (tsulatsi mujarrad), namun tidak satu jenis karena berbeda pada komposisi akarnya. Nama 'Tsabita' berasal dari verba ثَبَتَ /tsabatal 'tetap' atau 'stabil'. Dalam kamus Al-Ma'any disebutkan bahwa kata tersebut bermakna tetap di satu tempat dan tidak bergerak. Pada nama diri Indonesia ini, terjadi perubahan vokal kedua antara kata bahasa Arab dan nama diri Indonesianya, yaitu dari vokal /a/ 
menjadi /i/. Namun hal tersebut tidak mengakibatkan perubahan makna. Verba ini termasuk kepada strong verbs karena akar-akarnya terdiri dari fonem-fonem yang kuat.

Adapun nama 'Faza' berasal dari kata bahasa Arab فَازَ/faaza/ 'berhasil'. Verba ini termasuk kepada weak verbs karena akar keduanya terdiri dari fonem lemah yaitu I /alif/. Pada nama diri Indonesia ini, fonem tersebut dihilangkan karena bahasa Indonesia tidak mengenal pemanjangan vokal. Dalam kamus $A l$ Mu'ashirah disebutkan bahwa فَاز /faaza/ bermakna mencapai, meraih ataupun memperoleh sesuatu, seperti penghargaan tingkat nasional.

\subsection{Nama Diri Kategori Adjektiva}

Nama diri orang berbahasa Arab di Indonesia ditemukan pula yang berkategori adjektiva atau shifat. Adapun jenis adjektiva yang ditemukan pada nama diri berbahasa Arab ini terdapat dua jenis gender yaitu maskulin (mudzakkar) dan feminin (muannats), sebagaimana terlihat dalam Tabel 3.

Tabel 3

Nama Diri Kategori Adjektiva

\begin{tabular}{ll}
\hline \multicolumn{1}{c}{ Nama Diri } & Jenis Adjektiva \\
\hline Fakhri & Maskulin \\
\hline Akbar & Maskulin \\
\hline Jamilah & Feminin \\
\hline
\end{tabular}

Nama 'Fakhri', 'Akbar' dan 'Jamilah' merupakan nama diri orang yang diambil dari kata bahasa Arab berkategori adjektiva karena menunjukkan suatu sifat. Sifat dalam bahasa Arab digunakan untuk menjelaskan nomina, oleh karena itu dituntut beberapa persesuaian antara kata yang menjadi sifat dan kata yang disifatinya. Salah satunya adalah persesuaian gender. Maka sifat dalam bahasa Arab berdasarkan gendernya, terbagi menjadi maskulin dan feminin. Sifat yang bergender feminin biasanya ditandai dengan sufiks o/ta marbutah/.

Adapun nama 'Fakhri' merupakan nama yang berasal dari kata sifat bahasa Arab فَخْرُ /fakhrun/ 'bangga' atau 'sombong', bergender maskulin karena tidak diakhiri dengan sufiks : / ta marbuthah/. Meskipun memiliki makna sifat, berdasarkan ilmu nahwu atau gramatika bahasa Arab seperti disebutkan dalam kamus Al-Mu'ashirah, kata tersebut merupakan bentuk isim mashdar yang diturunkan dari verba triliteral Ifakharal 'membanggakan diri'.

Nama 'Akbar' terambil dari kata bahasa Arab أََْبَرَ /akbaru/ 'lebih atau paling besar' dan termasuk kepada adjektiva bergender maskulin. Namun kata tersebut termasuk pula kepada jenis isim tafdhil yaitu bentuk komparatif atau 
superlatif dalam bahasa Arab. Adjektiva tersebut berasal dari kata كَبْيَ /kabiirun/ 'besar' yang dimasukkan kepada pola isim tafdhil أَفْعَُ /af'alu/ sehingga bermakna lebih atau paling besar jika dibandingkan dengan yang lain.

Di antara nama diri bahasa Arab yang bergender feminin adalah 'Jamilah'. Nama diri orang 'Jamilah' berasal dari

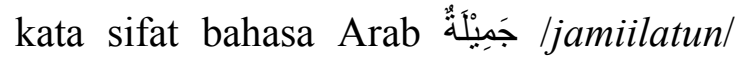
'indah' atau 'cantik', termasuk kata sifat feminin karena diakhir oleh sufiks $\ddot{o} /$ ta marbuthah/. Dalam bahasa Arab, pelafalan sufiks :/ta marbuthah/ tersebut berubah menjadi fonem $/ h /$ apabila di-waqaf-kan atau berada di akhir kalimat atau pengucapan. Oleh karena itu, dianggap tepat menyerap kata tersebut menjadi 'Jamilah' menggunakan fonem /h/ untuk sebuah nama diri orang. Dalam kamus $\mathrm{Al}$ Muhith disebutkan bahwa kata جَمِيْلِ /jamiilun/ memiliki makna seseorang yang tersifati dengan keindahan atau kebaikan akhlaknya. Sedangkan dalam kamus $A l$ Mu'ashirah dijelaskan bahwa kata tersebut merupakan bentuk shifat musyabbahah yang diturunkan dari verba جَمُلْ /jamula/ 'indah'.

\subsection{Nama Diri Kategori Numeralia}

Kategori kelas kata terakhir yang ditemukan dalam nama diri orang berbahasa Arab di Indonesia adalah numeralia. Dalam gramatika bahasa Arab, numeralia memang tidak dikategorikan sebagai kelas kata, namun bentuk dan konsepnya tetap ditemukan bahkan dengan kaidah yang sangat rinci. Sesuai dengan jenis pembagiannya, terdapat dua jenis numeralia yang dijadikan nama diri orang di Indonesia, yaitu numeralia pokok ('adad) dan numeralia tingkatan (murattab) sebagaimana dalam Tabel 4.

\section{Tabel 4}

Nama Diri Kategori Numeralia

\begin{tabular}{ll}
\hline Nama Diri & \multicolumn{1}{c}{ Jenis Numeralia } \\
\hline Alfa & Numeralia Pokok \\
\hline Tsany & Numeralia Tingkatan \\
\hline
\end{tabular}

Nama 'Alfa' dan 'Tsany' termasuk kepada kategori numeralia karena mengindikasikan bilangan. Nama 'Alfa' sendiri berasal dari kata bahasa Arab أَلْفْ lalfun/ yang bermakna 'seribu'. Kata tersebut termasuk kepada jenis numeralia pokok atau 'adad dalam bahasa Arab. Dalam kamus Al-Ma'any disebutkan bahwa maknanya adalah عَثْرَ مِنَّاتٍ / 'asyra miaat/ 'sepuluh ratus' yakni 'seribu'. Sedangkan nama 'Tsany' termasuk kepada numeralia tingkatan atau murattab. Nama tersebut berasal dari kata ثَانِي /tsaanii/ 'kedua' sebagai bentuk murattab dari nomina pokok إنتْنَّن /itsnaini/ 'dua' yang dimasukkan kepada pola atau wazan فَاعِلِ /faa'ilun/. Sesuai dengan artinya, nama 
tersebut biasanya digunakan oleh orang Indonesia untuk menamakan anak keduanya.

Dari hasil analisis data nama diri orang berbahasa Arab di Indonesia, dapat terlihat bahwa setiap nama termasuk kepada kategori kelas kata tertentu dalam bahasa Arab, baik yang berasal dari nama diri juga dalam bahasa Arab maupun yang berasal dari kosakata atau istilah berbahasa Arab. Setiap nama diri bahasa Arab itu memiliki makna-makna tertentu sebagaimana pola yang dibentuk dari pembentukan kata tersebut. Adapun makna yang terkandung di dalamnya, ternyata tidak semuanya merupakan hal yang positif. Ada beberapa nama mengandung konotasi negatif karena merupakan salah satu sifat yang tidak terpuji. Hal tersebut dikarenakan orang tua yang memberi nama tidak mengkaji lebih jauh mengenai makna nama yang akan diberikan kepada anaknya.

\section{Penutup}

Berdasarkan hasil analisis pada pembahasan, dapat disimpulkan bahwa nama diri orang berbahasa Arab di Indonesia secara morfologis terbagi kepada empat jenis kategori kelas kata. Empat jenis kategori tersebut adalah: 1) nomina (isim), yang terdiri dari nomina nama diri (isim 'alam), nomina jenis (isim jinsi), nomina subjektif (isim fa'il), nomina objektif (isim maf'ul) dan nomina deverba (isim mashdar); 2) verba, yang terdiri dari strong verbs (verba shahih) dan weak verbs (verba mu'tal); 3) adjektiva (shifat), yang terdiri dari sifat bergender maskulin (mudzakkar) dan feminin (muannats); 4) numeralia ('adad), yang terdiri dari numeralia pokok ('adad) dan numeralia tingkatan (murattab), serta tidak ditemukan bentuk nama diri berkategori partikel atau harf. Dari penelitian ini diketahui bahwa nama diri orang Indonesia berbahasa Arab berdasarkan analisis morfo-semantik lebih banyak diambil dari kategori nomina dibandingkan kelas kata lainnya dan tidak ditemukan nama yang berasal dari kelas kata partikel dalam bahasa Arab.

\section{Daftar Pustaka}

Achsani, F. 2020. Dari Generasi Milenial Hingga Generasi Alfa: Analisis Nama Masyarakat Banaran-Bugel. Mabasan: Masyarakat Bahasa \& Sastra Nusantara, 14(1), 1-16.

Akmaluddin, N. 2018. Realitas Penggunaan Bahasa Indonesia Ragam Tulisan Pada Lembaga Pemerintahan. Mabasan: Masyarakat Bahasa \& Sastra Nusantara, 12(1), 1-20. 
Aprilia, L. 2016. Kosakata Toponimi Kota Pangkalpinang. Mabasan: Masyarakat Bahasa \& Sastra Nusantara, 10(1), 68-84.

Al-Ghulayaini, M. 2017. Jami'ud Durusil 'Arabiyyah. Cairo: Al-Sahoh.

Hakim, A. 2017. Representasi Nama Diri dalam Pemilihan Rektor Universitas Gadjah Mada 2012: Sebuah Kajian Semiotik. Mabasan: Masyarakat Bahasa \& Sastra Nusantara, 11(1), 18-31.

Hidayah, M., Samingin, F. X., \& Wijayanti, A. 2018. Kata Serapan bahasa Arab dalam Kosakata Bahasa Indonesia sebagai Materi Pembelajaran Ceramah di Kelas XI SMA: Kajian Bidang Fonologi. Repetisi: Riset Pendidikan Bahasa dan Sastra Indonesia, 1(November).

Kamus Al-Ma'any. 2020. Diakses pada tanggal 12 Desember 2020.

Kamus Al-Mu'ashirah. 2020. Diakses pada tanggal 12 Desember 2020.

Kamus Al-Muhith. 2020. Diakses pada tanggal 12 Desember 2020.

KBBI Daring. 2020. Diakses pada tanggal 12 Desember 2020.

Khotimah, K. dan Febriani, I. 2019. Kajian Semantik Nama Diri Mahasiswa Madura di Prodi Pendidikan Bahasa dan Sastra Indonesia Universitas Trunojoyo Madura. Jurnal Pendidikan Bahasa Dan Sastra Indonesia, 8(1), 51-55.

Moeliono, A. M., dkk. 2017. Tata Bahasa Baku Bahasa Indonesia. Jakarta: Badan Pengembangan dan
Pembinaan Bahasa, Kementerian Pendidikan dan Kebudayaan.

Nur, T. 2018. Sintaksis Bahasa Arab. Bandung: Unpad Press.

Nur, T. 2018. Morfologi Bahasa Arab. Bandung: Unpad Press.

Pulungan, H. R., Suhono, N., \& Sumarlam, N. 2019. Serapan Bahasa Arab Pada Budaya Akikah Ni Daganak Tubu Berbahasa Angkola. Ranah: Jurnal Kajian Bahasa, 8(1), 33.

Rohbiah, T. S. 2017. Perubahan Makna Kata Serapan Bahasa Arab dalam Bahasa Inggris pada Istilah Ekonomi. Buletin Al-Turas, 23(2).

Sudaryanto. 2015. Metode dan Aneka Teknik Analisis Bahasa. Yogyakarta: SDU Press.

Sugiyono. 2013. Metode Penelitian Kombinasi (Mixed Methods). Bandung: Alfabeta.

Ubaidillah, U. 2012. Interferensi Penggunaan Nama Diri Berbahasa Arab di Indonesia (Sebuah Kajian Sosiolinguistik). Adabiyyāt: Jurnal Bahasa Dan Sastra, 10(1), 1. 
